\title{
Oral Administration in Combination with Zinc Enhances $\beta$-Cryptoxanthin-Induced Anabolic Effects on Bone Components in the Femoral Tissues of Rats in Vivo
}

\author{
Masayoshi Yamaguchi, ${ }^{*}, a$ Satoshi UchiYama, ${ }^{a}$ Kaori Ishiyama, ${ }^{b}$ and Ken Hashimoto ${ }^{b}$ \\ ${ }^{a}$ Laboratory of Endocrinology and Molecular Metabolism, Graduate School of Nutritional Sciences, University of \\ Shizuoka; 52-1 Yada, Suruga-ku, Shizuoka 422-8526, Japan: and ${ }^{b}$ Institute for Health Science, Yamada Apiculture Center, \\ Inc.; 194 Ichiba, Kagamino-cho, Tomata-gun, Okayama 708-0393, Japan.
}

Received September 12, 2005; accepted November 2, 2005

The effects of combined $\beta$-cryptoxanthin and zinc on bone components in the femoral-diaphyseal (cortical bone) and -metaphyseal (trabecular bone) tissues of rats in vivo were investigated. Rats were orally administered either vehicle, $\beta$-cryptoxanthin ( 5 or $10 \mu \mathrm{g} / 100 \mathrm{~g}$ body weight), zinc sulfate $(0.1$ or $0.5 \mathrm{mg} \mathrm{Zn/100} \mathrm{g),} \mathrm{or} \mathrm{their} \mathrm{com-}$ bination once a day for $7 \mathrm{~d}$. Calcium content, alkaline phosphatase activity, and DNA content in the femoral-diaphyseal tissues was not significantly altered by the administration of $\beta$-cryptoxanthin $(5 \mu \mathrm{g} / 100 \mathrm{~g})$ or zinc $(0.1$ or $0.5 \mathrm{mg} / 100 \mathrm{~g})$. Combined administration of $\beta$-cryptoxanthin $(5 \mu \mathrm{g} / 100 \mathrm{~g})$ and zinc $(0.1 \mathrm{or} 0.5 \mathrm{mg} / 100 \mathrm{~g})$ caused a synergistic increase in calcium content, alkaline phosphatase activity, and DNA content in the diaphyseal tissues. The effect of $\beta$-cryptoxanthin (5 or $10 \mu \mathrm{g} / 100 \mathrm{~g}$ ) in increasing calcium and DNA contents in the metaphyseal tissues was significantly enhanced by the combined administration of zinc $(0.1 \mathrm{or} 0.5 \mathrm{mg} / 100 \mathrm{~g})$, but did not have a significant effect on the metaphyseal components. The metaphyseal alkaline phosphatase activity was markedly increased by the combination of $\beta$-cryptoxanthin $(5 \mu \mathrm{g} / 100 \mathrm{~g})$ and zinc $(0.1 \mathrm{or} 0.5 \mathrm{mg} / 100 \mathrm{~g})$. This study demonstrates that the oral administration of the combination of zinc at lower doses synergistically enhances $\beta$-cryptoxanthin-induced anabolic effects on bone components in the femoral tissues of rats in vivo.

Key words $\beta$-cryptoxanthin; zinc; bone formation; rat femur

Bone mass decreases with increasing age. This decrease is due to increased bone resorption and reduced bone formation. The decrease in bone mass induces osteoporosis, which is widely recognized as a major public health problem. The most dramatic expression of this disease is represented by fractures of the proximal femur. ${ }^{1-3)}$ Pharmacologic and nutritional factors may prevent bone loss with increasing age. ${ }^{4,5}$ Chemical compounds in food that act on bone metabolism, however, are poorly understood.

Carotenoids are present in fruit and vegetables. Carotenoids have been shown to have a possible biological effect in cancer prevention. ${ }^{6}$ Retinol (vitamin A) is known to have a detrimental effect on bone at high doses. In laboratory animals, high levels of vitamin A lead to accelerated bone resorption, bone fractures, and osteoporotic bone lesions. ${ }^{7-9)}$ $\beta$-Cryptoxanthin is a carotenoid that is abundant in Satsuma mandarin (Citrus unshiu MARC.) and it is enzymatically converted from $\beta$-carotene (provitamin $\mathrm{A}$ ) in plants. Of the various carotenoids (including $\beta$-cryptoxanthin, lutein, lycopene, and $\beta$-carotene) and rutin (quercetin-3-rutinoside), $\beta$-cryptoxanthin has been found to have a unique anabolic effect on bone calcification in rat femoral tissues in vitro. ${ }^{10,11)}$ Lutein, lycopene, $\beta$-carotene, and rutin had no effect on bone calcification in vitro. ${ }^{10)}$ Moreover, $\beta$-cryptoxanthin has been shown to have a stimulatory effect on osteoblastic bone formation and an inhibitory effect on osteoclastic bone resorption in vitro. ${ }^{11-14)}$ Oral administration of $\beta$-cryptoxanthin may have a preventive effect on bone loss with increasing age and on osteoporosis in vivo. ${ }^{15-18)}$

Zinc, an essential trace element, has been shown to have a potent stimulatory effect on osteoblastic bone formation and an inhibitory effect on osteoclastic bone resorption in vitro. ${ }^{19-24)}$ Oral administration of zinc compounds prevents bone loss in ovariectomized rats, an animal model of osteoporosis. ${ }^{25,26)}$

Whether the combination of pharmacologic with nutritional factors exhibits an additive or synergistic effect on bone components has not been fully clarified. This knowledge may be important in preventing bone loss with increasing age. More recently, it has been shown that the combination of $\beta$-cryptoxanthin and zinc at relatively low doses can enhance the anabolic effects on bone components in rat femoral tissues in vitro. ${ }^{27)}$ This study was undertaken to determine whether the combination of low-dose $\beta$-cryptoxanthin and zinc sulfate has anabolic effects on bone components in rats in vivo.

\section{MATERIALS AND METHODS}

Chemicals $\beta$-Cryptoxanthin (100\% purity) was obtained from Extrasynthese (Lyon-Nord, France). Zinc sulfate and other chemicals were of reagent grade and obtained from Wako Pure Chemical Industries, Ltd. (Osaka, Japan). All water used was glass distilled.

Animals Male Wistar rats (4 weeks old) were obtained from Japan SLC (Hamamatsu, Japan). The animals were fed commercial laboratory chow (solid) containing $57.4 \% \mathrm{Ca}$ and $1.1 \% \mathrm{P}$ for $7 \mathrm{~d}$ at room temperature of $25^{\circ} \mathrm{C}$ and had free access to distilled water.

Administration Procedures $\beta$-Cryptoxanthin was dissolved in corn oil at a concentration of 5 or $10 \mu \mathrm{g} /$ $0.5 \mathrm{ml} / 100 \mathrm{~g}$ body weight and orally administered to rats through a stomach tube once daily for $7 \mathrm{~d}$. Control rats received corn oil $(0.5 \mathrm{ml} / 100 \mathrm{~g}$ body weight $)$ orally. Zinc sulfate was dissolved in distilled water at a concentration of 0.1 or $0.5 \mathrm{mg} / \mathrm{ml} / 100 \mathrm{~g}$ body weight and orally administered to 
Table 1. Body Weight and Serum Components in Rats Orally Administered $\beta$-Cryptoxanthin (CRP) and Zinc

\begin{tabular}{|c|c|c|c|c|}
\hline \multirow[b]{2}{*}{ Treatment } & \multirow{2}{*}{$\begin{array}{c}\text { Body } \\
\text { weight } \\
\text { (g) }\end{array}$} & \multicolumn{3}{|c|}{ Serum concentration } \\
\hline & & $\begin{array}{c}\text { Zinc } \\
(\mu \mathrm{g} / \mathrm{dl})\end{array}$ & $\begin{array}{l}\text { Calcium } \\
(\mathrm{mg} / \mathrm{dl})\end{array}$ & $\begin{array}{l}\text { Inorganic phosphorus } \\
(\mathrm{mg} / \mathrm{dl})\end{array}$ \\
\hline Control & $112.8 \pm 3.4$ & $138.0 \pm 3.7$ & $10.09 \pm 0.14$ & $8.28 \pm 0.15$ \\
\hline $\mathrm{CRP}(5 \mu \mathrm{g} / 100 \mathrm{~g})$ & $115.1 \pm 5.0$ & $140.1 \pm 4.5$ & $10.11 \pm 0.19$ & $8.45 \pm 0.20$ \\
\hline CRP $(10 \mu \mathrm{g} / 100 \mathrm{~g})$ & $110.5 \pm 4.7$ & $136.9 \pm 2.3$ & $10.01 \pm 0.25$ & $8.31 \pm 0.22$ \\
\hline Zinc $(0.1 \mathrm{mg} / 100 \mathrm{~g})$ & $115.3 \pm 4.1$ & $160.8 \pm 6.8^{*}$ & $10.32 \pm 0.30$ & $8.40 \pm 0.31$ \\
\hline$+\mathrm{CRP}(5 \mu \mathrm{g} / 100 \mathrm{~g})$ & $109.8 \pm 6.5$ & $169.5 \pm 4.4 *$ & $9.83 \pm 0.26$ & $8.71 \pm 0.27$ \\
\hline$+\mathrm{CRP}(10 \mu \mathrm{g} / 100 \mathrm{~g})$ & $114.3 \pm 1.9$ & $177.3 \pm 9.6^{*}$ & $9.97 \pm 0.26$ & $8.56 \pm 0.25$ \\
\hline Zinc $(0.5 \mathrm{mg} / 100 \mathrm{~g})$ & $117.0 \pm 5.8$ & $165.1 \pm 8.0 *$ & $10.2 \pm 0.25$ & $8.29 \pm 0.32$ \\
\hline$+\mathrm{CRP}(5 \mu \mathrm{g} / 100 \mathrm{~g})$ & $116.3 \pm 1.7$ & $163.2 \pm 2.5^{*}$ & $9.98 \pm 0.21$ & $8.19 \pm 0.16$ \\
\hline$+\mathrm{CRP}(10 \mu \mathrm{g} / 100 \mathrm{~g})$ & $109.0 \pm 4.1$ & $176.6 \pm 9.2 *$ & $10.30 \pm 0.28$ & $8.78 \pm 0.25$ \\
\hline
\end{tabular}

Rats were orally administered either vehicle, $\beta$-cryptoxanthin ( 5 or $10 \mu \mathrm{g} / 100 \mathrm{~g}$ body weight), zinc $(0.1 \mathrm{or} 0.5 \mathrm{mg} / 100 \mathrm{~g})$ or $\beta$-cryptoxanthin $(5$ or $10 \mu \mathrm{g} / 100 \mathrm{~g})$ plus zinc $(0.1$ or $0.5 \mathrm{mg} / 100 \mathrm{~g}$ ) once daily for $7 \mathrm{~d}$. Each value is the mean \pm S.E.M. of six rats. $* p<0.01$ compared with the control value.

rats $30 \mathrm{~min}$ after the administration of $\beta$-cryptoxanthin once daily for $7 \mathrm{~d}$. Control rats received distilled water $(0.5 \mathrm{ml} / 100 \mathrm{~g}$ body weight $)$ orally. The animals were killed $24 \mathrm{~h}$ after the last administration by cardiac puncture under light ether anesthesia, and the blood and femur were removed immediately.

Analytical Procedures Blood samples were centrifuged for $30 \mathrm{~min}$ after collection, and the serum was separated. Serum zinc, calcium, and inorganic phosphorus concentrations were measured using an assay kit (Wako Pure Chemical Industries, Ltd.).

The femurs were soaked in ice-cold $0.25 \mathrm{M}$ sucrose solution. The femur was cleaned of soft tissue and marrow, and the diaphysis and metaphysis (not containing epiphyseal tissue) were separated. The femoral-diaphyseal and -metaphyseal tissues were cut into small pieces. The diaphyseal and metaphyseal tissues were dried for $16 \mathrm{~h}$ at $110^{\circ} \mathrm{C}$. Calcium content was determined using atomic absorption sepectrophotometry. ${ }^{19)}$ The calcium content in bone tissues is expressed as milligrams/gram of dry bone.

To assay alkaline phosphatase activity, the diaphyseal and metaphyseal tissues were immersed in $3.0 \mathrm{ml}$ of ice-cold $6.5 \mathrm{~mm}$ barbital buffer ( $\mathrm{pH} 7.4$ ), cut into small pieces, homogenized with a physcotron homogenizer, and disrupted for $60 \mathrm{~s}$ with an ultrasonic device. The supernatant centrifuged at $600 \times \mathbf{g}$ for $5 \mathrm{~min}$ was used to measure enzyme activity. Enzyme assay was carried out under optimal conditions. Alkaline phosphatase activity was determined using the method of Walter and Schutt. ${ }^{28)}$ Enzyme activity was expressed as $\mu \mathrm{mol}$ of $p$-nitrophenol liberated $/ \mathrm{min} / \mathrm{mg}$ of protein. The protein concentration was determined using the method of Lowry et al. ${ }^{29)}$

To measure bone DNA content, the diaphyseal and metaphyseal tissues were shaken with $4.0 \mathrm{ml}$ of ice-cold $0.1 \mathrm{M}$ $\mathrm{NaOH}$ solution for $24 \mathrm{~h}$ after homogenization of the bone tissues. ${ }^{30)}$ After alkali extraction, the samples were centrifuged at $10000 \times \boldsymbol{g}$ for $5 \mathrm{~min}$ and the supernatant was collected. The DNA content in the supernatant was determined using the method of Ceriotti ${ }^{31)}$ and expressed as the amount of DNA $(\mathrm{mg}) / \mathrm{g}$ wet weight of bone tissue.

Statistical Analysis The significance of differences between values was estimated using Student's $t$-test. We also used multiple ANOVA to compare the treatment groups. A $p$ value of less 0.05 was considered to indicate a statistically significant difference.

\section{RESULTS}

The changes in body weight and serum components in rats orally administered $\beta$-cryptoxanthin, zinc sulfate, or their combination for $7 \mathrm{~d}$ are shown in Table 1 . The body weight and serum calcium and inorganic phosphorus concentrations were not significantly altered by the oral administration of $\beta$ cryptoxanthin (5 or $10 \mu \mathrm{g} / 100 \mathrm{~g}$ body weight), zinc $(0.1$ or $0.5 \mathrm{mg} / 100 \mathrm{~g}$ ) or their combination. The serum zinc concentration was significantly increased by the administration of zinc $(0.1$ or $0.5 \mathrm{mg} / 100 \mathrm{~g})$. This increase was not significantly changed with the administration of $\beta$-cryptoxanthin.

The changes in the calcium content in the femoral-diaphyseal and -metaphyseal tissues of rats orally administered $\beta$ cryptoxanthin, zinc sulfate, or their combination for $7 \mathrm{~d}$ are shown in Fig. 1. The diaphyseal calcium content was not significantly changed with the administration of $\beta$-cryptoxanthin $(5 \mu \mathrm{g} / 100 \mathrm{~g})$ as compared with that in control rats, and it was not significantly altered by the administration of zinc $(0.1$ or $0.5 \mathrm{mg} / 100 \mathrm{~g})$. However, the diaphyseal calcium content was significantly increased with the combined administration of $\beta$-cryptoxanthin $(5 \mu \mathrm{g} / 100 \mathrm{~g})$ plus zinc $(0.1$ or $0.5 \mathrm{mg} / 100 \mathrm{~g})$. The administration of $\beta$-cryptoxanthin $(10 \mu \mathrm{g} / 100 \mathrm{~g})$ caused a significant increase in the diaphyseal calcium content. This increase was significantly enhanced with the combined administration of zinc $(0.1$ or $0.5 \mathrm{mg} /$ $100 \mathrm{~g})$. The metaphyseal calcium content was significantly increased with the administration of $\beta$-cryptoxanthin ( 5 or $10 \mu \mathrm{g} / 100 \mathrm{~g})$, but not significantly changed with the administration of zinc $(0.1$ or $0.5 \mathrm{mg} / 100 \mathrm{~g})$. The effects of $\beta$-cryptoxanthin (5 or $10 \mu \mathrm{g} / 100 \mathrm{~g}$ ) in increasing metaphyseal calcium content were synergistically enhanced by the combined administration of zinc $(0.1$ or $0.5 \mathrm{mg} / 100 \mathrm{~g})$.

Alkaline phosphatase activity in the femoral-diaphyseal and -metaphyseal tissues was not significantly changed with the administration of $\beta$-cryptoxanthin $(5 \mu \mathrm{g} / 100 \mathrm{~g}$ body weight), while it was significantly increased with the administration of $\beta$-cryptoxanthin (10 $\mu \mathrm{g} / 100 \mathrm{~g}$ ) (Fig. 2). The enzyme activity in the diaphyseal and metaphyseal tissues was not significantly changed with the administration of zinc $(0.1$ or $0.5 \mathrm{mg} / 100 \mathrm{~g})$. The combined administration of $\beta$-cryptoxanthin $(5 \mu \mathrm{g} / 100 \mathrm{~g})$ plus zinc $(0.1 \mathrm{mg} / 100 \mathrm{~g})$ caused a re- 


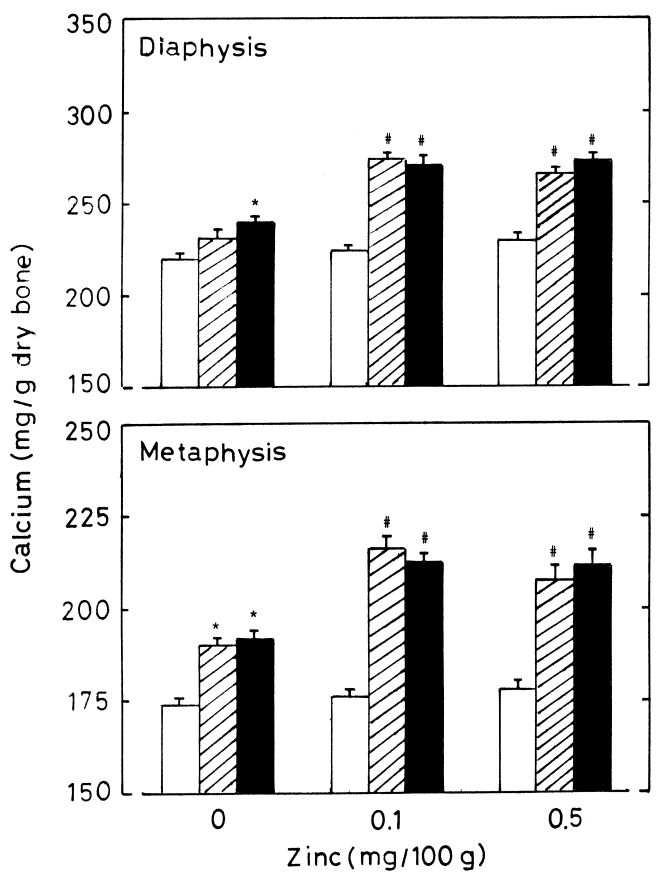

Fig. 1. Effects of Administration of Combined $\beta$-Cryptoxanthin and Zinc on Calcium Content in Femoral-Diaphyseal and -Metaphyseal Tissues of Rats in Vivo

The procedure of administration is described in the legend to Table 1. Each value is the mean \pm S.E.M. of six rats. $* p<0.01$ compared with the control (none) value. $\# p<0.01$ compared with the value obtained from the group of $\beta$-cryptoxanthin or zinc alone. White bars, control; hatched bars, $\beta$-cryptoxanthin $(5 \mu \mathrm{g} / 100 \mathrm{~g})$; black bars, $\beta$ cryptoxanthin $(10 \mu \mathrm{g} / 100 \mathrm{~g})$

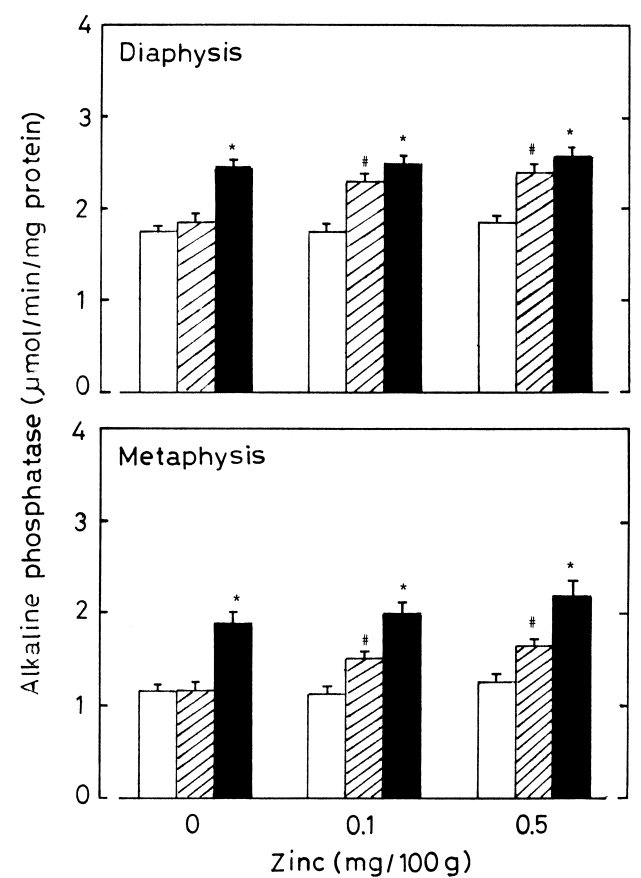

Fig. 2. Effects of Administration of Combined $\beta$-Cryptoxanthin and Zinc on Alkaline Phosphatase Activity in Femoral-Diaphyseal and -Metaphyseal Tissues of Rats in Vivo

The procedure of administration is described in the legend to Table 1. Each value is the mean \pm S.E.M. of six rats. $* p<0.01$ compared with the control (none) value. $\# p<0.01$ compared with the value obtained from the group of $\beta$-cryptoxanthin or zinc alone. White bars, control; hatched bars, $\beta$-cryptoxanthin $(5 \mu \mathrm{g} / 100 \mathrm{~g})$; black bars, $\beta$ cryptoxanthin $(10 \mu \mathrm{g} / 100 \mathrm{~g})$.

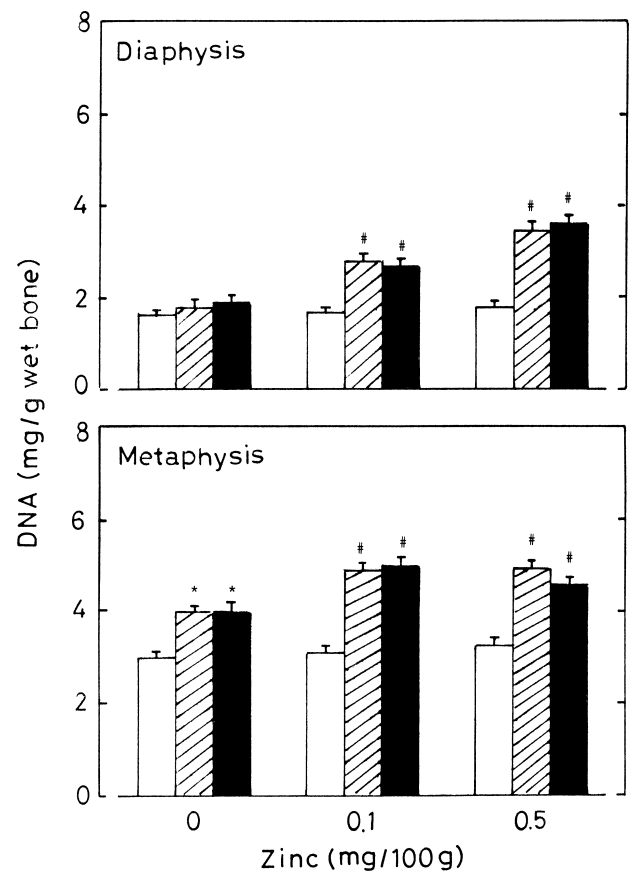

Fig. 3. Effects of Administration of Combined $\beta$-Cryptoxanthin and Zinc on DNA Content in Femoral-Diaphyseal and -Metaphyseal Tissues of Rats in Vivo

The procedure of administration is described in the legend to Table 1. Each value is the mean \pm S.E.M. of six rats. $* p<0.01$ compared with the control (none) value. ${ }^{\#} p<0.01$ compared with the value obtained from the group of $\beta$-cryptoxanthin or zinc alone. White bars, control; hatched bars, $\beta$-cryptoxanthin $(5 \mu \mathrm{g} / 100 \mathrm{~g})$; black bars, $\beta$ cryptoxanthin $(10 \mu \mathrm{g} / 100 \mathrm{~g})$

markable increase in the enzyme activity in the diaphyseal and metaphyseal tissues (Fig. 2).

DNA content in the diaphyseal tissues was not significantly altered by the oral administration of $\beta$-cryptoxanthin ( 5 or $10 \mu \mathrm{g} / 100 \mathrm{~g}$ ) or zinc $(0.1$ or $0.5 \mathrm{mg} / 100 \mathrm{~g}$ ) for $7 \mathrm{~d}$ (Fig. $3)$. The diaphyseal DNA content was synergistically increased with the combined administration of $\beta$-cryptoxanthin $(5 \mu \mathrm{g} / 100 \mathrm{~g})$ plus zinc $(0.1 \mathrm{mg} / 100 \mathrm{~g})$ or $\beta$-cryptoxanthin $(10 \mu \mathrm{g} / 100 \mathrm{~g})$ plus zinc $(0.5 \mathrm{mg} / 100 \mathrm{~g})$. The metaphyseal DNA content was significantly increased with the administration of $\beta$-cryptoxanthin ( 5 or $10 \mu \mathrm{g} / 100 \mathrm{~g}$ ). This increase was significantly enhanced with the combined administration of $\beta$-cryptoxanthin ( 5 or $10 \mu \mathrm{g} / 100 \mathrm{~g}$ ) plus zinc $(0.1$ or $0.5 \mathrm{mg} / 100 \mathrm{~g}$ ) (Fig. 3). Meanwhile, the administration of zinc $(0.1$ or $0.5 \mathrm{mg} / 100 \mathrm{~g})$ did not have a significant effect on the metaphyseal DNA content.

\section{DISCUSSION}

Bone loss with increasing age induces osteoporosis. Food chemical factors may help to prevent bone loss with aging. Bone loss may be due to decreased bone formation and increased bone resorption. Of the various carotenoids, $\beta$-cryptoxanthin has been shown to have a stimulatory effect on osteoblastic bone formation and an inhibitory effect on osteoclastic bone resorption in vitro. ${ }^{10-14)}$ Meanwhile, zinc has a potent stimulatory effect on osteoblastic bone formation. ${ }^{19-21,32)}$ More recently, it has been found that the combination of $\beta$-cryptoxanthin and zinc at comparatively low doses has a potent anabolic effect on bone components in the femoral-diaphyseal (cortical bone) and -metaphyseal (trabec- 
ular bone) tissues of rats in vitro. ${ }^{27)}$ Such an effect was not observed with the combination of $\beta$-cryptoxanthin and other food factors (including genistein or menaquinone-7) which have an anabolic effect on bone components. ${ }^{33-36)}$ Thus the enhancing effect with the combination of $\beta$-cryptoxanthin and zinc appears unique. ${ }^{27)}$

This study found that the oral administration of the combination of zinc with of comparatively low dose for $7 \mathrm{~d}$ markedly enhances $\beta$-cryptoxanthin-induced anabolic effects on bone components (including calcium content, alkaline phosphatase activity, and DNA content) in the femoral-diaphyseal or -metaphyseal tissues of rats in vivo. Alkaline phosphatase is an enzyme marker of osteoblasts, and the enzyme participates in bone mineralization. ${ }^{37)}$ DNA content in bone tissues is an index of the number of bone cells. ${ }^{38)}$ The enhanced effects with the combination of $\beta$-cryptoxanthin and zinc on bone components in vivo may be related to the stimulatory effects on osteoblastic bone formation.

Serum calcium and inorganic phosphorus concentrations were not significantly altered by the administration of combined $\beta$-cryptoxanthin and zinc in rats. It is assumed that the effects of $\beta$-cryptoxanthin and zinc in increasing bone calcium content do not involve calcium-regulating hormones to maintain serum calcium homeostasis. Moreover, the increase in the serum zinc concentration was not significantly altered by the administration of $\beta$-cryptoxanthin. The enhanced effects with the combination of $\beta$-cryptoxanthin and zinc in increasing bone components was not related to the enhancement of serum zinc concentration. Presumably, the enhanced effect with the combination of $\beta$-cryptoxanthin and zinc on bone components mainly resulted from a direct action of both compounds on bone tissues in rats, since bone components have been shown to increase in the presence of $\beta$-cryptoxanthin and zinc in femoral tissue culture systems in vitro. ${ }^{27)}$ However, the possibility cannot be excluded that the oral administration of combined $\beta$-cryptoxanthin and zinc modulates the effects of bone-regulating hormones on bone components.

$\beta$-Cryptoxanthin has been shown to have an effect on nuclear factor to stimulate transcriptional activity in osteoblastic cells in vitro. ${ }^{12,13)}$ Meanwhile, zinc has been demonstrated to activate aminoacyl-tRNA synthase, a rate-limiting enzyme of protein synthesis as a translational process, in osteoblastic cells in vitro. ${ }^{19,39)}$ Bone DNA content was increased with the oral administration of $\beta$-cryptoxanthin and zinc in rats. It is speculated that the combination of $\beta$-cryptoxanthin and zinc has stimulatory effects on gene expression, protein synthesis, and cell proliferation in osteoblastic cells in rat femoral tissues. This may contribute to their enhancing effect on bone components in femoral tissues of rats in vivo.

Food chemical factors may help to prevent bone loss with aging. Dietary intake with the combination of $\beta$-cryptoxanthin and zinc may have a role in the prevention of osteoporosis. In conclusion, it has been demonstrated that the oral administration of low-dose zinc synergistically enhances $\beta$ cryptoxanthin-induced anabolic effects on bone components in the femoral tissues of rats in vivo.

\section{REFERENCES}

1) Schapira C., Slinn S., Sarid M., Mokadai S., Kabala A., Silbermann M., Bone, 16, 575-582 (1995).

2) Wild R. A., Buchamain J. R., Meyers C., Demers L. M., Proc. Soc. Exp. Biol. Med., 186, 335-360 (1987).

3) Cooper C., Melton J., III, Trends Endocrinol. Metab., 3, 224-229 (1992).

4) Bonjour J.-P., Schurch M.-A., Rizzori R., Bone, 18, 1395-1445 (1996).

5) Muhlbauer R. C., Li F., Nature (London), 401, 343-344 (1999).

6) Stenmetz K. A., Potter J. D., J. Am. Diet. Assoc., 96, 1027-1033 (1996).

7) Forsyth K. S., Watoson R. R., Gensler H. L., Life Sci., 45, 2149—2156 (1989).

8) Rohde C. M., Manatt M., Clagett-Dome M., DeLuca H. F., J. Nutr., 129, 2241-2250 (1999).

9) Promislow J. H. F., Goodman-Gruen D., Barret-Conncer E., Slymen D. J., J. Bone Miner. Res., 17, 1349-1358 (2002).

10) Yamaguchi M., Uchiyama S., Biol. Pharm. Bull., 26, 1188-1191 (2003).

11) Yamaguchi M., Uchiyama S., Mol. Cell. Biochem., 258, 137-144 (2004).

12) Uchiyama S., Yamaguchi M., Int. J. Mol. Med., 15, 675-681 (2005).

13) Uchiyama S., Yamaguchi M., J. Cell. Biochem., 95, 1224-1234 (2005).

14) Uchiyama S., Yamaguchi M., Biochem. Pharmacol., 67, 1297-1305 (2004).

15) Uchiyama S., Sumida T., Yamaguchi M., Biol. Pharm. Bull., 27, 232 235 (2004).

16) Uchiyama S., Sumida T., Yamaguchi M., J. Health Sci., 50, 491-496 (2004).

17) Uchiyama S., Yamaguchi M., Biol. Pharm. Bull., 28, 1766-1769 (2005).

18) Yamaguchi M., Igarashi A., Uchiyama S., Morita S., Sugawara K., Sumida T., J. Health Sci., 50, 619-624 (2004).

19) Yamaguchi M., Oishi H., Suketa Y., Biochem. Pharmacol., 37, 40754080 (1988).

20) Hashizume M., Yamaguchi M., Mol. Cell. Biochem., 122, 59-64 (1993).

21) Yamaguchi M., Hashizume M., Mol. Cell. Biochem., 136, 163-169 (1994).

22) Yamaguchi M., Segawa Y., Shimokawa N., Tsuzuike N., Tagashira E., Pharmacology, 45, 292-300 (1992).

23) Kishi S., Yamaguchi M., Biochem. Pharmacol., 48, 1225-1230 (1994).

24) Yamaguchi M., Uchiyama S., Int. J. Mol. Med., 14, 81-85 (2004).

25) Kishi S., Segawa Y., Yamaguchi M., Biol. Pharm. Bull., 17, 862-865 (1994).

26) Yamaguchi M., Kishi S., Jpn. J. Pharmacol., 63, 203-207 (1993).

27) Uchiyama S., Ishiyama K., Hashimoto K., Yamaguchi M., Biol. Pharm. Bull., 28, 2142-2145 (2005).

28) Walter K., Schutt C., "Methods of Enzymatic Analysis," ed. by Bergmeyer H. U., Academic Press, New York, 1965, pp. 856-860.

29) Lowry O. H., Rosebrough N. J., Farr A. L., Randall R. J., J. Biol. Chem., 193, 265-273 (1951).

30) Flanagan B., Nichols G. J., J. Biol. Chem., 237, 3686-3692 (1962).

31) Ceriotti G., J. Biol. Chem., 214, 39-77 (1955).

32) Yamaguchi M., Inamoto K., Suketa Y., Res. Exp. Med., 186, 337-342 (1986).

33) Gao Y. H., Yamaguchi M., Biochem. Pharmacol., 58, 767-772 (1999).

34) Yamaguchi M., Sugimoto E., Mol. Cell. Biochem., 214, 97-102 (2000).

35) Sugimoto E., Yamaguchi M., Int. J. Mol. Med., 5, 515-520 (2000).

36) Yamaguchi M., Sugimoto E., Hachiya S., Mol. Cell. Biochem., 223, $131-137$ (2001).

37) Majeska R. J., Wuthier R. E., Biochem. Biophys. Acta, 391, 51-60 (1975).

38) Canalis E., Centrella M., Bunch W., McCarthy T. L., J. Clin. Invest., 83, 60-65 (1989).

39) Yamaguchi M., Kishi S., Hashizume M., Peptides, 15, 1367-1371 (1994). 